\title{
Rooting of Stem Cuttings of Jatropha platyphylla (Euphorbiaceae) in the Obtaining of Axillary Buds for Grafting
}

\author{
Edith Salazar-Villa1, Miguel Angel Angulo-Escalante1, Jesús Diego Castro-Valenzuela², \\ Karla Marina Báez-Parra ${ }^{3}$, Lluvia de Abril Alexandra Soriano-Melgar ${ }^{4}$, Federico Soto-Landeros ${ }^{*}$
}

${ }^{1}$ Centro de Investigación en Alimentación y Desarrollo A.C., Culiacán, México

${ }^{2}$ Universidad Autónoma de Occidente, Guasave, México

${ }^{3}$ Facultad de Ciencias Químico Biológicas, Universidad Autónoma de Sinaloa, Culiacán, México

${ }^{4}$ Centro de Investigación en Química Aplicada, Saltillo, México

${ }^{5}$ Instituto Tecnológico Superior de Guasave, Guasave, México

Email: ^federico.sl@guasave.tecnm.mx

How to cite this paper: Salazar-Villa, E., Angulo-Escalante, M.A., Castro-Valenzuela, J.D., Báez-Parra, K.M., de Abril Alexandra Soriano-Melgar, L. and Soto-Landeros, F. (2021) Rooting of Stem Cuttings of Jatropha platyphylla (Euphorbiaceae) in the Obtaining of Axillary Buds for Grafting. American Journal of Plant Sciences, 12, 1880-1893. https://doi.org/10.4236/ajps.2021.1212130

Received: October 5, 2021

Accepted: December 25, 2021

Published: December 28, 2021

Copyright $\odot 2021$ by author(s) and Scientific Research Publishing Inc. This work is licensed under the Creative Commons Attribution International License (CC BY 4.0).

http://creativecommons.org/licenses/by/4.0/

(c) (i) Open Access

\begin{abstract}
Jatropha platyphylla is considered as a potential source of edible protein, oil, and phenolic compounds with anti-inflammatory activity. The use of stem cutting in vegetative propagation and grafting is as indispensable tools for mass multiplication of superior genotypes and helps in improve planting yield and quality. The study was aimed to investigate the effect of different diameters (10 - 15, $16-25$ and $26-35 \mathrm{~mm})$ and different hormone concentrations of indo-butyric acid $(0,1.5,3,6$ and $10 \mathrm{~g} / \mathrm{L})$, in the rooting of Jatropha platyphylla and to obtain axillary buds to performed grafts. Rooting efficiency was $80 \%$ in greenhouse conditions. Hormone concentration and diameter significantly affected the rooting and shooting ability of Jatropha platyphylla stem cuttings. Stem cuttings of $26-35 \mathrm{~mm}$ have the greatest number, length and dry root weight. $76 \%$ survival of the grafted plants was obtained. This demonstrates the necessity to improve the conventional propagation methods with appropriate scientific inputs for more economical and time efficient techniques for standard propagation protocols.
\end{abstract}

\section{Keywords}

Axillary Buds, Graft, Stem Cutting, Plant Breeding, Varietal Selection 


\section{Introduction}

Jatropha platyphylla (Euphorbiaceae) is a perennial plant. It is considered as a potential source of edible protein and oil [1], and the leaves and fruits are rich in phenolic compounds with anti-inflammatory activity [2]. J. platyphylla such as $J$. curcas, forms artificial and natural hybrid complexes readily and has a problem with genetic fidelity [3].

Jatropha can propagate through seeds, cuttings and tissue culture [4]. Seed propagation may not produce high quality planting materials, due to short viability, poor seed germination, and high heterozygosity [5] [6]. Vegetative propagation through cutting or by tissue culture can be the most effective alternatives to produce quality seedlings with desirable traits for higher seed and oil yield. Vegetative propagation has inimitable significance to maintain homogeneity among the progeny and provide early production [7]. Plants originated from stem cuttings obtained more shoot structures (buds, stems, and leaves) [8]. Nevertheless, but these plants show a lower longevity and possess a lower drought and disease resistance than those propagated by seeds [9]. Plants produced from cuttings do not produce true taproots that may penetrate only one-half the depth of the soil compared to taproots produced on seed grown plants [10]. Parameter such as the length, position on the branch, diameter of stem cutting can influence survival rate and plant development in Jatropha [7].

Previous studies have shown the importance of plant hormones for differentiation of cells in the formation of roots [11]. Auxins facilitates root production from branch cuttings, and the effectiveness varies with season and concentrations of micronutrients [12] [13]. The possibility of combining sexual and asexual reproduction systems in oil crops is the key strategy to develop new cultivars [14]. Propagation by grafting is a frequently used in agriculture to increase uniformity, vigor and resistance to biotic and abiotic stresses [15] [16] [17]. Grafting allows to hastening plant growth rate and earlier fruit production and conserve plants of genetic importance (elite) [16].

Grafting is the method of inserting a part of the plant (scion part of the graft that produces the new system buds of one $\mathrm{cm}$ diameter $\mathrm{x}$ ten $\mathrm{cm}$ of length, varieties depending on what the breeder desires) onto the root system (rootstock lower part of the graft that possesses a root system, is often categorized according to tree vigor, in their resistance to pests and disease, and in their influence on fruiting) of another plant [15]. Grafting method can be exploited in Jatropha platyphylla for the development of sustainable cultivation of at commercial scale. In addition, genetic stability has been demonstrated in grafted plants, obtaining $100 \%$ genetic stability between the mother and the grafted plant [18]. In order to attain plants with a consistent quality and yield, vegetative propagation is beneficial. The experiments reported in this article aimed to study the influence of stem cutting diameter and different concentrations of hormone indo-butyric acid (IBA) on the processes of sprouting, rooting, and initial growth of J. platyphylla, with the purpose of increasing the clonal multiplication of an elite plant, and also to observe the rate of survival of the graft. 


\section{Materials and Methods}

\subsection{Plant Material}

Stem cuttings and seeds were obtained from a 24 months-old experimental plot of $J$. platyphylla in La Campana, Sinaloa, Mexico $\left(24^{\circ} 59^{\prime} 28^{\prime \prime} \mathrm{N}\right.$ and $\left.107^{\circ} 34^{\prime} 25^{\prime \prime} \mathrm{W}\right)$ at 97 masl. The plants of $J$. platyphylla were selected, with vigorous stems and apparently pest and disease free. The stems were collected, at the beginning of the physiological dormancy.

\subsection{Rooting of Stem Cuttings}

Stem cuttings were washed with soap (Axion $3 \mathrm{~cm}^{3} / \mathrm{L}$ ) and subsequently washed by distilled water. The stems were cut into segments of $40 \mathrm{~cm}$ in length with at least three buds, and three groups were formed according to the diameter of the stem (10 - 15, 16 - 25 and $26-35 \mathrm{~mm}$ ). The axillary buds were removed from the base of the cuttings with scalpel and lesions were performed in the bark to expose the tissue (vascular cambium) and improve the penetration of the hormonal solution RADIX ${ }^{-}$. The basal portion of the cuttings was treated in the different concentrations of indole-3-butyric acid (IBA) as 1.5, 3, 6 and $10 \mathrm{~g} / \mathrm{L}$ distilled water for $12 \mathrm{~h}$. The treated cuttings were also compared with the control (treated with distilled water only) (Table 1). After treatment, they were planted in

Table 1. Combinations between the diameters of Jatropha platyphylla stem cuttings and the concentrations of indo-butyric acid (IBA).

\begin{tabular}{ccc}
\hline Treatments & Diameters $(\mathrm{mm})$ & Concentration $(\mathrm{IBA}$ g/L) \\
\hline 1 & $10-15$ & 0 \\
2 & $10-15$ & 1.5 \\
3 & $10-15$ & 3.0 \\
4 & $10-15$ & 6.0 \\
5 & $10-15$ & 10.0 \\
6 & $16-25$ & 0 \\
7 & $16-25$ & 1.5 \\
8 & $16-25$ & 3.0 \\
9 & $16-25$ & 6.0 \\
10 & $16-25$ & 10.0 \\
11 & $26-35$ & 0 \\
12 & $26-35$ & 1.5 \\
13 & $26-35$ & 3.0 \\
14 & $26-35$ & 6.0 \\
15 & $26-35$ & 10.0 \\
\hline
\end{tabular}

$\mathrm{mm}=$ millimeters; $\mathrm{g} / \mathrm{L}=$ grams per liter 
polythene bag filled with substrate BERGER ${ }^{\circledast}$ (perlite $10 \%$, vermiculite $10 \%$ and peat moss $80 \%$ ) moistened to field capacity; and introduced in vertical position at $10 \mathrm{~cm}$ depth approximately. Cuttings were transferred to greenhouse at room temperature and visible developing buds were counted at 90 days after planting (DAP) (March-May 2018), from the developed stem cuttings the data were taken (number and length of sprouted axillary buds, number and length of root and root dry weight). The root dry weight was determined, using a $\mathrm{YAMATO}^{\circ}$ stove at $70^{\circ} \mathrm{C}$ for a period of $48 \mathrm{~h}$. The management of the cuttings in the greenhouse was carried out with irrigation at the beginning of the week and another at the end of the week. The control of pests (insects and mites) was achieved using Confirdor ${ }^{\oplus}$ and Agrimec $^{\oplus}$ respectively, at the doses recommended by the manufacturer.

\subsection{Seed Germination}

200 J. platyphylla seeds were washed with detergent Axion (Colgate-Palmolive, Mexico City, MX) and subsequently washed by distilled water. Seeds were dipped in $10 \%$ commercial sodium hypochlorite Cloralex ${ }^{\circledast}$ (Industrias Alen, Nuevo Leon, MX) for $15 \mathrm{~min}$ and washed five times with distilled water; they were soaked in distilled water for a $24 \mathrm{~h}$ period at room temperature to soften the seed coat and allow a homogeneous germination [19]. The seeds were placed in sterile paper wetted in sterile water for their germination and incubated in a growth chamber at $25^{\circ} \mathrm{C} \pm 2{ }^{\circ} \mathrm{C}$ in dark conditions. Germinated were sowed in $250 \mathrm{~mL}$ polyethylene cups, perforated on the base and filled with vegetable transplant growing mix BERGER ${ }^{ø}$ and incubated in a growth chamber at $25^{\circ} \mathrm{C} \pm 2{ }^{\circ} \mathrm{C}$ and periods of $12 \mathrm{~h}$ light and $12 \mathrm{~h}$ darkness. Germination percentage was evaluated. Seedlings were placed in a polycarbonate greenhouse in light and temperature conditions at $28^{\circ} \mathrm{C} \pm 7^{\circ} \mathrm{C}$. Subsequently they were used for grafts.

\subsection{Graft}

Thirty-day seedlings $(\mathrm{N}=100)$, with similar stem diameter and height, were cut to use them as rootstock, and a V-shaped cut was made under the cotyledons discarding the aerial part to avoid growth of axillary shoots found in the knot of the cotyledon leaves (Figure 1(a)). On the other hand, the axillary bud attains of stem cuttings of J. platyphylla (graft) was cut in the form of an arrow in such a way that it joins the rootstock (Singh et al. 2009) (Figure 1(b)). The grafting parts were joint perfectly and covered with Parafilm ${ }^{\oplus}$ (Figure 1(c)) (American National Can, CT, U.S.A.) tape to hold them together and prevent the entrance of air (Figure 1(d)). The seedlings recently grafted were placed in a growth chamber at a temperature of $27^{\circ} \mathrm{C} \pm 2^{\circ} \mathrm{C}$ and relative humidity from $70 \%$ to $80 \%$. Grafted three month seedlings were transferred to $5 \mathrm{~L}$ of plastic pots with Soge$\mathrm{mix}^{\circledast}$ (CANADA) and perlite (Grupo Perlita, Torreon, Coahuila, MX) substrate ( $75 \%$ and $25 \%, \mathrm{~V} / \mathrm{V}$, respectively). The survival number of grafted plants was counted. 


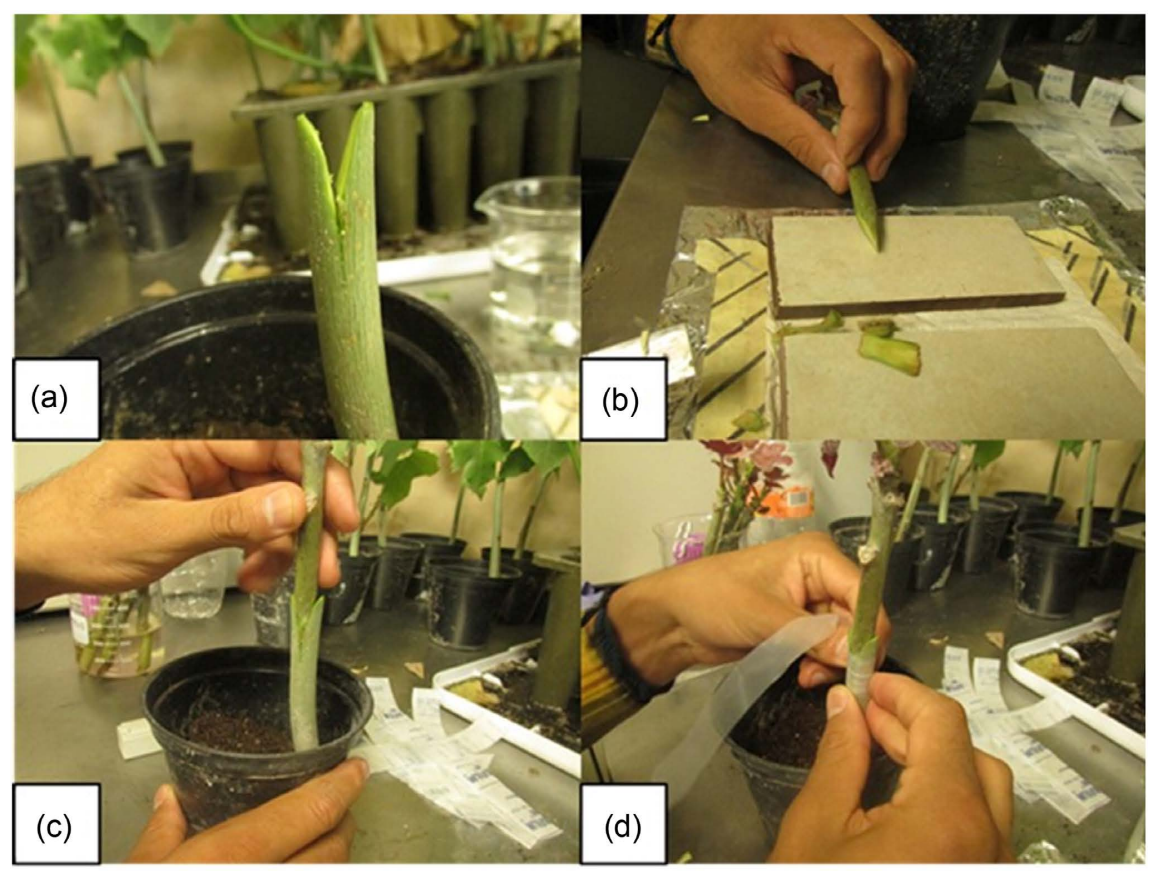

Figure 1. Grafting of Jatropha platyphylla: (a) rootstock "V"; (b) axillary bud "arrow"; (c) joint; and (d) use of Parafilm ${ }^{\circledast}$.

\subsection{Statistical Analysis}

A completely randomized statistical design and an analysis of variance (ANOVA) were used, to compare data between the different treatments. Each treatment was replicated thrice. To determine the interaction between stem cuttings diameter and IBA concentration, a two-factor analysis was used. Mean separation for different treatment were performed using Tukey test ( $\mathrm{p} \leq 0.05)$. All statistical analysis was performed by MINITAB $^{\circledast}$ version 17 .

\section{Results and Discussion}

\subsection{Root Formation and Sprouted Axillary Buds in Stem Cuttings of J. platyphylla}

The efficiency of rooted and developed stem cuttings was $80 \%$ in greenhouse conditions. The result of the diameter of the stem cuttings on the formation, development and growth of roots is significantly different, being that the stem cuttings of $26-35 \mathrm{~mm}$ have the greatest number, length and dry root weight, unlike the stem cuttings of $10-15 \mathrm{~mm}$ of lower efficiency. The stem cuttings with a diameter of $16-25 \mathrm{~mm}$ present intermediate characteristics in comparison to the two previous groups. The importance of the diameter in stem cuttings has been reported earlier with its biomass production such as roots [9] [20] [21]. This could be due to the variation of the concentration of stored carbohydrate which are root-forming substances. Most of the IBA treated cuttings produced greater number of roots as compared to control (distilled water). The effect of the hormonal concentration (IBA) of 6 and $10 \mathrm{~g} / \mathrm{L}$ presents significant differences, with respect to the concentrations of control, 1.5 and $3 \mathrm{~g} / \mathrm{L}$ and 25 to 35 
$\mathrm{mm}$ in diameter, this tendency is repeated in the three levels of the stem cuttings diameter factor (Table 2). The ones with the best development were those of 25 to $35 \mathrm{~mm}$ in diameter and of 6 to $10 \mathrm{~g} / \mathrm{L}$ indo-butyric acid (IBA). As for the concentration, the amount can be reduced up to $1.5 \mathrm{~g} / \mathrm{L}$, as long as stems cuttings of $30 \mathrm{~mm}$ to $50 \mathrm{~mm}$ in diameter are used. Similarly, the results agree with Osman and El-Naggar [22], who conducted two experiments with Jatropha curcas cuttings and seven IBA concentrations. Experiment 1: Two years old mature thick terminal branches $6-8 \mathrm{~cm}$ long and 3 - $4 \mathrm{~cm}$ of circumference; Experiment 2: Four years old mature thick terminal branches of $15-17 \mathrm{~cm}$ in length and 4 $5 \mathrm{~cm}$ of circumference. For the first experiment, the propagation $1500 \mathrm{ppm}$ IBA treatment was found to be the best $(6.8$ roots $/$ cutting, $1.32 \mathrm{~cm}$ root length, 71.1 rooting percentage, $3.1 \mathrm{~g}$ fresh weight, 1.5 leaves/cutting, $2.4 \mathrm{~cm}$ length of the longest leaf and 38 days to sprout). In the second experiment, the propagation $2.5 \mathrm{~g} / \mathrm{L} \mathrm{IBA}$ treatment was found to be the best $(8.3$ roots/cutting, $5.6 \mathrm{~cm}$ root length, 68.8 rooting percentage, $14.8 \mathrm{~g}$ fresh weight, 3.1 leaves/cutting, $4.6 \mathrm{~cm}$ length of the longest leaf and 50 days to sprout). However, Adekola and Akpan [23], mention that untreated cuttings had the best performance or were similar

Table 2. Effect of the diameters of Jatropha platyphylla stems cuttings and the concentrations of indo-butyric acid (IBA) in root formation.

\begin{tabular}{|c|c|c|c|c|c|}
\hline $\begin{array}{c}\text { Treatment } \\
\text { number }\end{array}$ & $\begin{array}{l}\text { Stem cuttings } \\
\text { diameter } \\
(\mathrm{mm})\end{array}$ & $\begin{array}{l}\text { Concentration } \\
\text { (IBA g/L) }\end{array}$ & $\begin{array}{l}\text { Number } \\
\text { of roots }\end{array}$ & $\begin{array}{l}\text { Length of } \\
\operatorname{root}(\mathrm{cm})\end{array}$ & $\begin{array}{l}\text { Dry weight } \\
\text { of root }(\mathrm{g})\end{array}$ \\
\hline 1 & $10-15^{\star} b$ & $0 \mathrm{~b}$ & $2.3 \pm 1.5 \mathrm{c}$ & $22.0 \pm 5.0 \mathrm{ab}$ & $0.299 \pm 0.13 d$ \\
\hline 2 & $10-15 b$ & $1.5 \mathrm{ab}$ & $6.0 \pm 1.7 c$ & $17.0 \pm 3.0 \mathrm{ab}$ & $0.445 \pm 0.10 \mathrm{~cd}$ \\
\hline 3 & $10-15 b$ & $3.0 \mathrm{ab}$ & $3.0 \pm 1.5 \mathrm{c}$ & $9.0 \pm 1.5 b$ & $0.367 \pm 0.30 \mathrm{~d}$ \\
\hline 4 & $10-15 b$ & $6.0 \mathrm{a}$ & $8.7 \pm 5.1 c$ & $16.0 \pm 6.1 \mathrm{ab}$ & $0.624 \pm 0.11 \mathrm{abcd}$ \\
\hline 5 & $10-15 b$ & $10.0 \mathrm{a}$ & $16.3 \pm 9.2 \mathrm{abc}$ & $20.3 \pm 1.2 \mathrm{ab}$ & $0.586 \pm 0.14 \mathrm{abcd}$ \\
\hline 6 & $15-25 a b$ & $0 \mathrm{~b}$ & $5.0 \pm 2.0 \mathrm{c}$ & $23.7 \pm 2.1 \mathrm{a}$ & $0.809 \pm 0.21 \mathrm{abcd}$ \\
\hline 7 & $15-25 a b$ & $1.5 \mathrm{ab}$ & $14.3 \pm 7.5 \mathrm{abc}$ & $19.0 \pm 3.0 \mathrm{ab}$ & $0.446 \pm 0.12 c d$ \\
\hline 8 & $15-25 a b$ & $3.0 \mathrm{ab}$ & $12.3 \pm 5.1 \mathrm{abc}$ & $19.5 \pm 1.5 \mathrm{ab}$ & $0.415 \pm 0.14 c d$ \\
\hline 9 & $15-25 a b$ & $6.0 \mathrm{a}$ & $16.7 \pm 1.5 \mathrm{abc}$ & $11.0 \pm 1.7 \mathrm{ab}$ & $0.545 \pm 0.12 \mathrm{abcd}$ \\
\hline 10 & $15-25 a b$ & $10.0 \mathrm{a}$ & $14.0 \pm 7.0 \mathrm{abc}$ & $21.3 \pm 2.1 \mathrm{ab}$ & $0.466 \pm 0.20 \mathrm{bcd}$ \\
\hline 11 & $26-35 a$ & $0 \mathrm{~b}$ & $2.7 \pm 1.5 c$ & $18.3 \pm 5.9 \mathrm{ab}$ & $0.171 \pm 0.10 \mathrm{~d}$ \\
\hline 12 & $26-35 a$ & $1.5 \mathrm{ab}$ & $16.0 \pm 5.2 \mathrm{abc}$ & $24.0 \pm 1.0 \mathrm{a}$ & $1.180 \pm 0.31 \mathrm{a}$ \\
\hline 13 & $26-35 a$ & $3.0 \mathrm{ab}$ & $19.7 \pm 1.5 \mathrm{abc}$ & $17.0 \pm 2.7 \mathrm{ab}$ & $1.049 \pm 0.15 \mathrm{abc}$ \\
\hline 14 & $26-35 a$ & $6.0 \mathrm{a}$ & $32.7 \pm 11.6 \mathrm{ab}$ & $16.7 \pm 5.9 \mathrm{ab}$ & $0.68 \pm 0.27 \mathrm{abcd}$ \\
\hline 15 & $26-35 a$ & $10.0 \mathrm{a}$ & $35.0 \pm 13.5 \mathrm{a}$ & $23.0 \pm 1.7 \mathrm{a}$ & $1.114 \pm 0.52 \mathrm{ab}$ \\
\hline
\end{tabular}

$\mathrm{mm}=$ millimeters; $\mathrm{cm}=$ centimeters; $\mathrm{g}=$ grams; $\mathrm{g} / \mathrm{L}=$ grams per Liter ${ }^{\star}$ Different letters within a row indicate significant differences. 
to the obtained in the highest concentrations of hormone in the variables, number and length of buds $(\mathrm{cm})$, length of root $(\mathrm{cm})$ and root dry weight $(\mathrm{g})$ at 90 days after planting. This could be due to the fact that growth hormones are not necessarily the main factor that influences root induction. The rooting of the cuttings can be influenced by other factors such as the physiological age [24] of the cuttings and the state of the rooting in terms of properties of aeration and drainage. The above may be true; however, the use of hormones accelerates the development and growth of roots in the stem cuttings in less time, which agrees with the aforementioned by Osman and El-Naggar [22], who obtained stem cuttings sprouted at 38 and 50 days after planting. As for the sprouted axillary buds, the ones with the best development were those from 25 to $35 \mathrm{~mm}$ in diameter. Regarding the application of indole-3-butyric acid to the apparently does not have an effect on the number and length of axillary buds. This may be due to the application being carried out via the root and the effect occurs indirectly. Another reason may be the time of development (90 DAP), which agrees with the aforementioned by Adekola and Akpan [23], of longer duration and greater vegetative growth.

In the interaction test, the order of the X's was exchanged, to provide two perspectives; first perspective (Figures 2(a)-(c)), second perspective (Figures 2(d)-(f)). In the number of roots there is no interaction between the three levels of stem cuttings diameter factor; however, an increase in root formation is observed, as the concentration of IBA increases (Figure 2(a)). In the second perspective there is interaction between the levels $(1.5,3,6$ and $10 \mathrm{~g} / \mathrm{L}$ of water) of the IBA concentration factor, when the diameter is $16-25 \mathrm{~mm}$ (Figure 2(d)). In the length of roots there is interaction between the three levels of stem cuttings diameter and the five levels IBA concentration in both perspectives (Figure 2(b) and Figure 2(e)). In the dry weight of roots there is no interaction between the level 26 - $35 \mathrm{~mm}$ and the levels $10-15$ and $16-25 \mathrm{~mm}$ of stem cuttings diameter factor; however, an increase in the dry weight is observed, as the concentration of IBA increases (Figure 2(c)). In the second perspective there is interaction between the five levels of the IBA concentration factor (Figure 2(f)).

The stem cuttings presented at least two developed axillary buds. The analysis of variance between treatments showed significant differences in the length of buds, according to the diameter, without affecting the number of sprouted buds, where there is no significant difference. The stem cuttings of $26-35 \mathrm{~mm}$ present the axillary buds with greater length (16 to $22 \mathrm{~cm}$ ); the stems of $10-15 \mathrm{~mm}$ and $16-25 \mathrm{~mm}$ present axillary buds with lengths ranging from 5 to $11 \mathrm{~cm}$ and from 6 to $16 \mathrm{~cm}$, respectively. The hormonal concentration (IBA) does not have an effect on the number and length of axillary buds in any of the three levels of the stem cuttings diameter factor (Table 3 ).

In the interaction test, the order of the X's was exchanged, to provide two perspectives; first perspective (Figure 3(a) and Figure 3(b)), second perspective (Figure 3(c) and Figure 3(d)). In the number of sprouted axillary buds there is interaction between the three levels of stem cuttings diameter factor, when the 


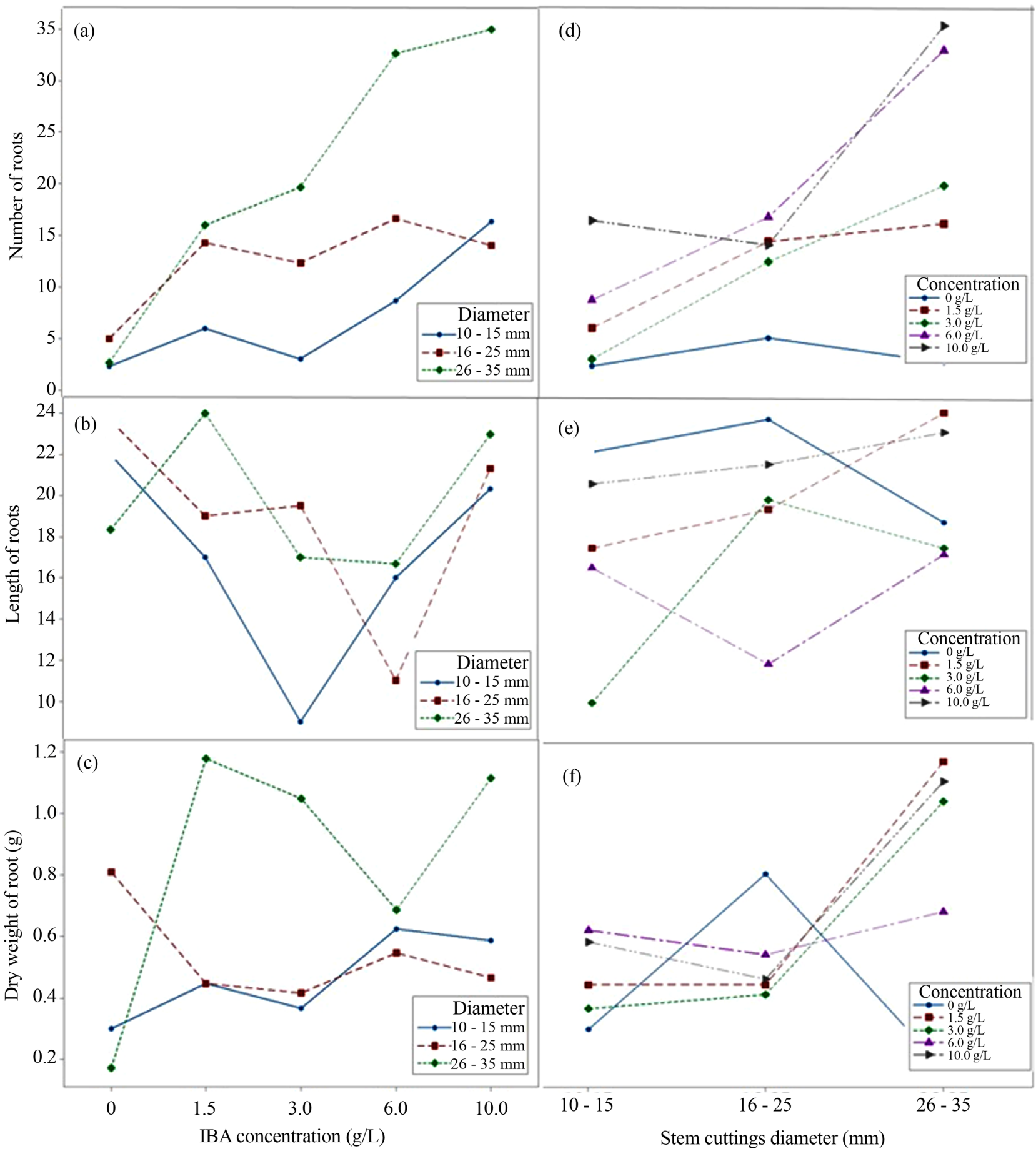

Figure 2. Interaction plot between stem cuttings and IBA concentration, in the root formation (number, length and dry weight), with two perspectives; first perspective ((a)-(c)), second perspective ((d)-(f)).

IBA concentration is of 6 to $10 \mathrm{~g} / \mathrm{L}$ (Figure 3(a)). In the second perspective there is interaction between the levels $(0,1.5,6$ and $10 \mathrm{~g} / \mathrm{L})$ of the IBA concentration factor, when the diameter is $16-25 \mathrm{~mm}$ (Figure $3(\mathrm{c})$ ). In the length of axillary buds there is no interaction between the three levels of stem cuttings diameter factor; however, an increase in the length of bud is observed, as the concentration 


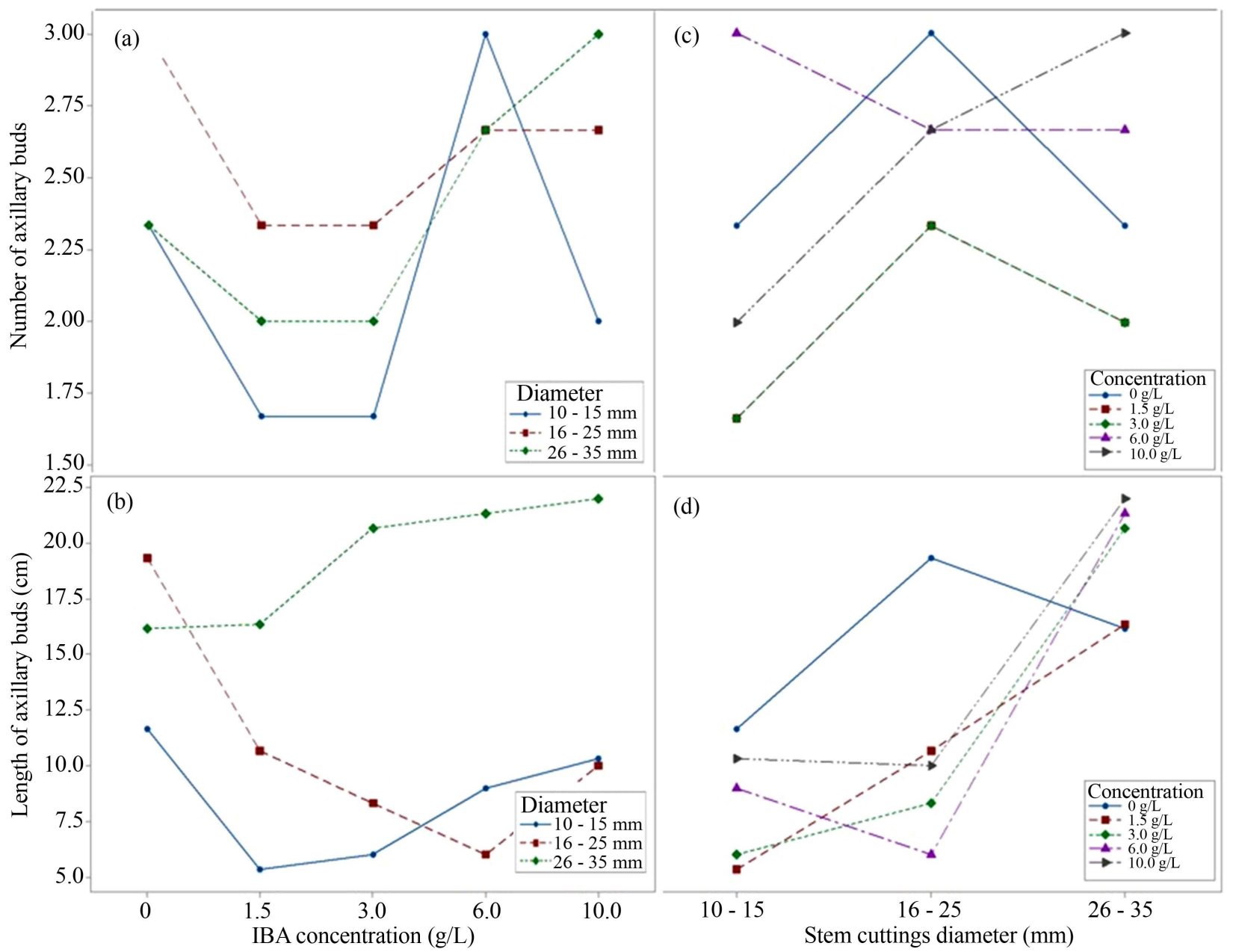

Figure 3. Interaction plot between stem cuttings and IBA concentration, in the axillary buds development (number and length), with two perspectives; first perspective ((a) and (b)), second perspective ((c) and (d)).

of IBA increases for the level $26-35 \mathrm{~mm}$, not being so for the other two levels 10 - 15 and $16-25 \mathrm{~mm}$ (Figure 3(b)). In the second perspective there is interaction between the entire IBA concentration factor, when the diameters are $16-25$ and $26-35 \mathrm{~mm}$ (Figure 3(d)).

\subsection{Seed Germination and Grafts}

The germination occurred at seven days in a heterogeneous way, reaching 58\% in total. The emergency was presented in the same way at 15 days after sowing. Seedlings were obtained for two months, with an average height of $30 \mathrm{~cm}$ and one $\mathrm{cm}$ in diameter. Heterogeneous germination is because the seeds of J. platyphylla, like other forest species, are difficult to germinate since the hard husk prevents the entry of water (physical latency), and the seed does not germinate unless the husk is scarified [25]. Another factor that may be affecting the percentage of germination is the state of physiological maturity; as mentioned by Budi et al. [26] who studied the viability of seeds of J. curcas in different stages of maturity of plants grown in an experimental field, finding that the best stage for 
Table 3. Effect of the diameters of Jatropha platyphylla stems cuttings and the concentrations of indo-butyric acid (IBA) in the growth and development of axillary buds.

\begin{tabular}{ccccc}
\hline $\begin{array}{c}\text { Treatment } \\
\text { number }\end{array}$ & $\begin{array}{c}\text { Stem cuttings } \\
\text { diameter }(\mathrm{mm})\end{array}$ & $\begin{array}{c}\text { Concentration } \\
\text { (IBA g/L) }\end{array}$ & $\begin{array}{c}\text { No. sprouted } \\
\text { axillary buds }\end{array}$ & $\begin{array}{c}\text { Length of axillar } \\
\text { buds }(\mathrm{cm})\end{array}$ \\
\hline 1 & $10-15^{\star} \mathrm{b}$ & $0 \mathrm{a}$ & $2.3 \pm 0.6 \mathrm{a}$ & $11.7 \pm 3.5 \mathrm{abcd}$ \\
2 & $10-15 \mathrm{~b}$ & $1.5 \mathrm{a}$ & $1.7 \pm 0.6 \mathrm{a}$ & $5.3 \pm 2.8 \mathrm{~d}$ \\
3 & $10-15 \mathrm{~b}$ & $3.0 \mathrm{a}$ & $1.7 \pm 0.6 \mathrm{a}$ & $6.0 \pm 1.0 \mathrm{~d}$ \\
4 & $10-15 \mathrm{~b}$ & $6.0 \mathrm{a}$ & $3.0 \pm 1.0 \mathrm{a}$ & $9.0 \pm 2.3 \mathrm{bcd}$ \\
5 & $10-15 \mathrm{~b}$ & $10.0 \mathrm{a}$ & $2.0 \pm 1.0 \mathrm{a}$ & $10.3 \pm 9.3 \mathrm{abcd}$ \\
6 & $16-25 \mathrm{~b}$ & $0 \mathrm{a}$ & $3.0 \pm 1.7 \mathrm{a}$ & $19.3 \pm 4.9 \mathrm{abc}$ \\
7 & $16-25 \mathrm{~b}$ & $1.5 \mathrm{a}$ & $1.0 \pm 1.0 \mathrm{a}$ & $10.7 \pm 1.2 \mathrm{abcd}$ \\
8 & $16-25 \mathrm{~b}$ & $3.0 \mathrm{a}$ & $2.3 \pm 0.6 \mathrm{a}$ & $8.3 \pm 5.8 \mathrm{~cd}$ \\
9 & $16-25 \mathrm{~b}$ & $6.0 \mathrm{a}$ & $2.7 \pm 0.6 \mathrm{a}$ & $6.0 \pm 3.0 \mathrm{~d}$ \\
10 & $16-25 \mathrm{~b}$ & $10.0 \mathrm{a}$ & $2.7 \pm 0.6 \mathrm{a}$ & $10.0 \pm 1.0 \mathrm{abcd}$ \\
11 & $26-35 \mathrm{a}$ & $0 \mathrm{a}$ & $2.3 \pm 1.2 \mathrm{a}$ & $16.2 \pm 3.3 \mathrm{abcd}$ \\
12 & $26-35 \mathrm{a}$ & $1.5 \mathrm{a}$ & $2.0 \pm 1.0 \mathrm{a}$ & $16.3 \pm 4.0 \mathrm{abcd}$ \\
13 & $26-35 \mathrm{a}$ & $3.0 \mathrm{a}$ & $2.0 \pm 1.7 \mathrm{a}$ & $20.7 \pm 3.5 \mathrm{abc}$ \\
\hline & $26-35 \mathrm{a}$ & $6.0 \mathrm{a}$ & $2.7 \pm 0.6 \mathrm{a}$ & $21.3 \pm 4.0 \mathrm{ab}$ \\
\hline & $26-35 \mathrm{a}$ & $10.0 \mathrm{a}$ & $3.0 \pm 2.0 \mathrm{a}$ & $22.0 \pm 5.3 \mathrm{a}$ \\
\hline
\end{tabular}

$\mathrm{mm}=$ millimeters; $\mathrm{cm}=$ centimeters; $\mathrm{g} / \mathrm{L}=$ grams per Liter ${ }^{\star}$ Different letters within a row indicate significant differences.

the germination of the seeds is the physiological maturity (yellow fruit). $76 \%$ survival of grafted plants was obtained. Callus formation was observed in the area of graft attachment and detachment of parafilm ${ }^{\otimes}$ as the thickness of the stem increased (Figure 4(a)). The stems in the grafted area were completely attached at day 15 after grafting, and showed successful compatibility between the stem tissues between the graft and the rootstock, developing as a single plant (Figure 4(b)).

The formation of calluses is observed in the area of union, confirmed the compatibility of tissues (Figure 4(a)). In callus, new parenchymatous cells proliferate fill up the spaces between the two components connecting the scion and the stock [18]. The success of a graft is mainly due to the following characteristics: 1) the graft and the rootstock are of the same species; 2) plants with a diameter similar to the graft were used; 3 ) anatomically, both parts have the same vascular tissues, which increased the probability of forming interconnections in less time [27]. The percentage of survival is similar to the average obtained by Cholid [28], who evaluated the compatibility of graft and the rootstocks of $J$. curcas, using 2 methods: lateral plating, using a diagonal and slit cut a cut in "V" 


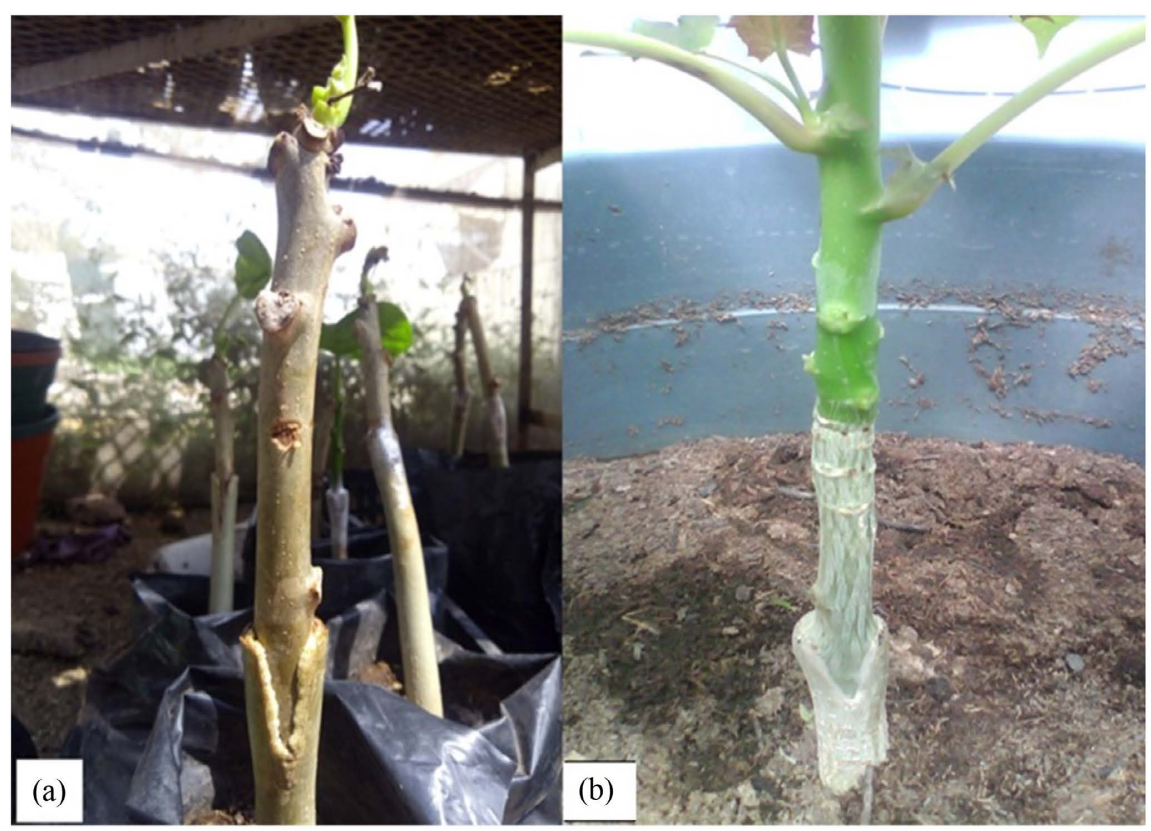

Figure 4. Formation of callus in the area of the union of the graft (a), and plant completely developed (b).

shape; with a pattern of 1,2 and 3 months. A survival of $78.6 \%$ was obtained, and the best method for grafting was the cut in the form of "V" and the rootstock of 2 and 3 months with a survival percentage of $89.5 \%$ and $93.8 \%$, respectively. The lateral plating graft method and the 1-month graft holder showed the lowest graft percentage of $66.5 \%$.

\section{Conclusion}

Vegetative and seed propagation techniques standardized for J. platyphylla successfully produced several seedlings. The realization of grafts reduces the juvenile period of the plant as well as the other techniques of asexual reproduction (in vitro culture, stem cuttings); however, the technique of grafting presents an advantage that the previous ones do not have, and this is that it provides a taproot, essential for tree stability. The rooting of stem cuttings to obtain lateral ramifications and then graft them, is a good option for the asexual multiplication of Jatropha platyphylla, since a greater number of individuals per tree can be obtained, in comparison with the production of cuttings, but lower than that obtained by in vitro culture and with the advantage of being more economical and time efficient. This demonstrates the necessity to improve the conventional propagation methods with appropriate scientific inputs for more economical and time efficient techniques for standard propagation protocols.

\section{Acknowledgements}

The authors thank Veronica Perez, Briceida Perez, Eduardo Sanchez, Werner Rubio and Jorge Manjarrez for technical assistance. Special thanks to Diana Fischer for English editing. 


\section{Conflicts of Interest}

The authors declare no conflicts of interest regarding the publication of this paper.

\section{References}

[1] Salazar-Villa, E., Alcaraz-Meléndez, L., León-Félix, J. Heredia J., Soto-Landeros F. and Angulo-Escalante M. (2020) Morphological Variability and Oil Content of Jatropha platyphylla Müll. Arg. Germplasm as Determined Using Multivariate Analysis. Scientia Horticulturae, 261, Article ID: 108968.

https://doi.org/10.1016/j.scienta.2019.108968

[2] Ambriz-Pérez, D., Bang, Y., Nair, V., Angulo-Escalante, M.A., Cisneros-Zevallos, L. and Heredia, J. (2016) Protective Role of Flavonoids and Lipophilic Compounds from Jatropha platyphylla on the Suppression of Lipopolysaccharide (LPS)-Induced Inflammation in Macrophage Cells. Journal of Agricultural Food Chemical, 64, 1899-1909. https://doi.org/10.1021/acs.jafc.5b05534

[3] Sosa-Segura, M., Oomah, B., Drover, J., Heredia, J., Osuna-Enciso, T., Valdez-Torres, J., Salazar-Villa, E., Soto-Landeros, F. and Angulo-Escalante, M.A. (2014) Physical and Chemical Characterization of Three Non-Toxic Oilseeds from the Jatropha Genus. Journal of Food and Nutrition Research, 2, 56-61.

[4] Datta, M., Mukherjee, P., Ghosh, B. and Jha, T. (2007) In Vitro Clonal Propagation of Biodiesel Plant (Jatropha curcas L.). Current Science, 93, 1438-1442.

[5] Islam, A., Islam, A., Anis-Nadhirah, N., Anuar, N. and Yaakob, Z. (2015) Propagation of Jatropha curcas through Seeds, Vegetative Cuttings and Tissue Culture. In: Medina, G., Ed., Jatropha curcas, Biology, Cultivation and Potential Uses, Nova Science Publisher New York, 131-158.

[6] Angulo-Escalante, M.A., Araiza-Lizarde, N. and Soto-Landeros, F. (2021) Multiplication Strategies and Agronomic Management of Jatropha elite. In: Heredia, J., Ed., Recent Studies on Jatropha Research, Nova Science Publishers, Inc., New York, 59-73.

[7] Timir, J., Mukherjee, P. and Datta, M. (2007) Somatic Embryogenesis in Jatropha curcas Linn., an Important Biofuel Plant. Plant Biotechnology Report, 1, 135-140. https://doi.org/10.1007/s11816-007-0027-2

[8] Montes, J. and Melchinger, A. (2016) Domestication and Breeding of Jatropha Curcas L. Trends in Plant Science, 21, 1045-1057. https://doi.org/10.1016/j.tplants.2016.08.008

[9] Severino, L., Lima, R., Lucena, A., Freire, M., Sampaio, L., Veras, R., Medeiros, K., Sofiatti, V. and Arriel, N. (2014) Propagation by Stem Cuttings and Root System Structure of Jatropha curcas. Biomass and Bioenergy, 35, 3160-3166. https://doi.org/10.1016/j.biombioe.2011.04.031

[10] Singh, A., Reddy, M., Chikara, J. and Singh, S. (2009) A Simple Regeneration Protocol from Stem Explants of Jatropha curcas-A Biodiesel Plant Industrial Crops and Products, 31, 209-213. https://doi.org/10.1016/j.indcrop.2009.10.007

[11] Ahmad, P. and Wani, M. (2013) Physiological Mechanisms and Adaptation Strategies in Plants under Changing Environment. Vol. 2, Springer Science \& Business Media, New York. https://doi.org/10.1007/978-1-4614-8600-8

[12] Kochhar, S., Singh, S. and Kochhar, V. (2008) Effect of Auxins and Associated Biochemical Changes during Clonal Propagation of the Biofuel Plant Jatropha curcas. Biomass and Bioenergy, 32, 1136-1143.

https://doi.org/10.1016/j.biombioe.2008.02.014 
[13] El-Kader, A., Hussein, M. and Alva, A. (2012) Response of Jatropha on a Clay Soil to Different Concentrations of Micronutrients. American Journal of Plant Sciences, 3, 1376-1381. https://doi.org/10.4236/ajps.2012.310166

[14] Dhillon, R., Hooda, M., Pundeer, J., Ahlawat, K. and Kumari, S. (2009) Development of Efficient Techniques for Clonal Multiplication of Jatropha curcas L., a Potential Biodiesel Plant. Current Science, 96, 823-827.

[15] Bijalwan, A. and Thakur, T. (2010) Effect of IBA and Age of Cuttings on Rooting Behavior of Jatropha Curcas L. in Different Seasons in Western Himalaya, India. African Journal of Plant Science, 4, 387-390.

[16] Louws, F.J., Rivard, C.L. and Kubota, C. (2010) Grafting Fruiting Vegetables to Manage Soilborne Pathogens, Foliar Pathogens, Arthropods and Weeds. Scientia Horticulturae, 127, 127-146. https://doi.org/10.1016/j.scienta.2010.09.023

[17] Bisognin, D. (2011) Breeding Vegetatively Propagated Horticultural Crops. Crop Breeding and Applied Biotechnology, 11, 35-43. https://doi.org/10.1590/S1984-70332011000500006

[18] Hassen, Y. and Hussen, S. (2015) Review on Role of Grafting on Yield and Quality of Selected Fruit Vegetables. Global Journal of Science Frontier Research: D Agriculture and Veterinary, 15, 1-17.

[19] Willan, R.L. (2000) Pre-tratamiento de Semillas. In: Centro Agronómico Tropical de Investigación y Enseñanza, Ed., Técnicas para la germinación de semillas, Turrialba, Costa Rica, 65-70.

[20] Achten, W., Maes, W., Reubens, B., Mathijs, E., Singh, V., Verchot, L. and Muys, B. (2010) Biomass Production and Allocation in Jatropha curcas L. Seedlings under Different Levels of Drought Stress. Biomass and Bioenergy, 34, 667-676. https://doi.org/10.1016/j.biombioe.2010.01.010

[21] Singh, A. and Agrawal, P.K. (2017) Jatropha curcas Micrografting Modifies Plant Architecture and Increases Tolerance to Abiotic Stress: Grafting Modifies the Architecture of Jatropha curcas. Plant Cell, Tissue Organ Culture, 128, 243-246. https://doi.org/10.1007/s11240-016-1098-y

[22] Osman, A. and El-Naggar, H.M. (2014) Rooting of Jatropha curcas L. and Euphorbia tirucalli Cuttings in Response to IBA and Planting Media in North Egypt: A Potential Source for Tomorrow's Oil, Biodiesel and Biofuels. Asian Journal of Crops Science, 6, 186-201. https://doi.org/10.3923/ajcs.2014.186.201

[23] Adekola, O. and Akpan, I. (2012) Effects of Growth Hormones on Sprouting and Rooting of Jatropha curcas I. Stem Cuttings. Journal of Applied Sciences and Environmental Management, 16, 165-168.

[24] Camellia, N., Thohirah, L., Abdullah, N. and Khidir, M. (2009) Improvement on Rooting Quality of Jatropha curcas Using Indole Butyric Acid (IBA). Research Journal of Agriculture and Biological Sciences, 5, 338-343.

[25] Poulsen, K. and Stubsgaard, F. (2000) Tres Métodos de Escarificación Mecánica de Semillas de Testa Dura. In: Centro Agronómico Tropical de Investigación y Enseñanza, Ed., Técnicas para la Escarificación de Semillas Forestales, Turrialba, Costa Rica, 121-125.

[26] Budi, S., Budianto, A. and Muliarta, A. (2012) Seed Viability of Jatropha curcas in Different Fruit Maturity Stages after Storage. Nusantara Bioscience, 4, 113-117.

[27] Jaganath, B., Subramanyam, K., Mayavan, S., Karthik, S., Elayaraja, D., Udayakumar, R. and Ganapathi, A. (2014) An Efficient in Plant Transformation of Jatropha curcas (L.) and Multiplication of Transformed Plants through in Vivo Grafting. Protoplasma, 251, 591-601. https://doi.org/10.1007/s00709-013-0558-Z 
[28] Cholid, M. (2014) Effects of Grafting Time and Grafting Methods Used on Scion and Rootstock Compatibility of Phisyc Nut (Jatropha curcas L.). Asian Journal of Agricultural Research, 8, 150-163. https://doi.org/10.3923/ajar.2014.150.163 